\title{
Improved Analysis Animals and Plants in My House (IPA) through The Discovery Learning Method Class IV
}

\author{
Wahyu Hidayat \\ SD Negeri 02 Tombo \\ wahyuhidayatwassegh@gmail.com
}

\begin{tabular}{|c|c|}
\hline Article History & \\
\hline
\end{tabular}

\begin{abstract}
In improving the achievement of students in science lessons, especially in the discussion of animals and plants in my home environment, the fourth grade students at SD Negeri Tombo 02 were selected using the discovery learning method. Discovery learning method is a teaching method that focuses on the activities of students in learning. In the learning process with this method, the teacher only acts as a guide and facilitator who directs students to find concepts, arguments, procedures, algorithms and the like. Thus students are encouraged to be more actively involved in learning materials and develop critical thinking skills in fourth grade students of SD Negeri Tombo 02, Bandar District, Batang Regency, 2020/2021 school year. After analyzing the value of the science learning process and results, the authors summarize the problems that occur in online learning, including: a. Students are less able to mention animals and plants, $b$. Students are less able to explain the parts of plant functions for humans, $c$. Students' perspectives are less able to explain the Indonesian landscape. From the results of the problem analysis above, it can be analyzed, including: Is the problem caused by inappropriate media or learning devices, learning materials that are not in accordance with the interests of students, or learning methods do not attract students?
\end{abstract}

Keywords: Improved analyzing with the discovery learning method

\begin{abstract}
Abstrak
Dalam meningkatkan prestasi belajar siswa pada pelajaran IPA khususnya dalam pembahasan hewan dan tumbuhan di lingkungan rumah saya, dipilih siswa kelas IV SD Negeri Tombo 02 dengan menggunakan metode discovery learning. Metode discovery learning merupakan metode pengajaran yang menitikberatkan pada aktivitas siswa dalam pembelajaran. Dalam proses pembelajaran dengan metode ini, guru hanya berperan sebagai pemandu dan fasilitator yang mengarahkan siswa untuk menemukan konsep, argumen, prosedur, algoritma dan sejenisnya. Dengan demikian siswa didorong untuk lebih aktif terlibat dalam pembelajaran materi dan mengembangkan keterampilan berpikir kritis pada siswa kelas IV SD Negeri Tombo 02 Kecamatan Bandar, Kabupaten Batang tahun pelajaran 2020/2021. Setelah menganalisis nilai proses dan hasil pembelajaran IPA, penulis merangkum permasalahan yang terjadi dalam pembelajaran online, diantaranya: a. Mahasiswa kurang mampu menyebutkan hewan dan tumbuhan, b. Mahasiswa kurang mampu menjelaskan bagian-bagian fungsi tumbuhan bagi manusia, c. Perspektif mahasiswa kurang mampu menjelaskan lanskap Indonesia. Dari hasil analisis masalah di atas dapat dianalisis, antara lain: Apakah masalah disebabkan oleh media atau perangkat pembelajaran yang tidak tepat, materi pembelajaran yang tidak sesuai dengan minat siswa, atau metode pembelajaran yang kurang menarik minat siswa?
\end{abstract}

Kata kunci: Peningkatan analisis dengan metode pembelajaran discovery

Social, Humanities, and Education Studies (SHEs): Conference Series p-ISSN 2620-9284 https://jurnal.uns.ac.id/shes

e-ISSN 2620-9292 


\section{PENDAHULUAN}

Pendidikan Nasional berfungsi mengembangkan kemampuan dan mencerdaskan kehidupan bangsa bertujuan untuk berkembangnya potensi peserta didik agar menjadi manusia beriman dan bertaqwa kepada Tuhan Yang Maha Esa, berahlak mulia, sehat, berilmu, cakap, kreatif, dan mandiri menjadi warga negara yang demokratis serta tanggung jawab, Undang-Undang Sisdiknas No. 20 tahun 2003.

Undang-Undang Nomor 14 tahun 2005, tentang guru menjelaskan bahwa Pembangunan Nasional dalam bidang pendidikan adalah upaya mencerdaskan kehidupan bangsa dan meningkatkan kualitas manusia Indonesia yang beriman, bertakwa, dan berakhlak mulia serta menguasai ilmu pengetahuan, teknologi, dan seni dalam mewujudkan masyarakat yang maju, adil, makmur, dan beradab berdasarkan Pancasila dan Undang-Undang Dasar Negara Republik Indonesia tahun 1945.

Pembelajaran secara sederhana dapat diartikan sebagai sebuah usaha mempengaruhi emosi, intelektual, dan spritual seseorang agar mau belajar dengan kehendaknya sendiri. Melalui pembelajaran akan terjadi proses pengembangan moral keagamaan, aktivitas, dan kreativitas peserta didik melalui berbagai interaksi dan pengalaman belajar. Pembelajaran berbeda dengan mengajar yang pada prinsipnya menggambarkan aktivitas guru, sedangkan pembelajaran menggambarkan aktivitas peserta didik.

Belajar adalah suatu proses yang kompleks yang terjadi pada diri setiap orang sepanjang hidupnya. Hasil dari belajar adalah adanya perubahan sikap dan tingkah laku pada diri orang itu disebabkan terjadinya perubahan pada tingkat pengetahuan, keterampilan dan sikapnya. Perubahan tersebut hendaknya terjadi sebagai akibat interaksi dengan lingkungannya, tidak karena proses pertumbuhan fisik atau kedewasaan, tidak karena kelelahan, penyakit atau pengaruh obat-obatan. Pengaruh tersebut harus bersifat relatif permanen,tahan lama dan mantap, tidak berlangsung sesaat saja.

Pada hakekatnya kegiatan belajar mengajar adalah suatu sistem pendidikan di Indonesia ternyata telah mengalami banyak perubahan. Perubahan-perubahan itu terjadi karena telah dilakukan berbagai usaha pembaharuan dalam pendidikan. Akibat pengaruh itu pendidikan semakin mengalami kemajuan. Sejalan dengan kemajuan tersebut, maka dewasa ini pendidikan di sekolah-sekolah telah menunjukkan perkembangan yang sagat pesat. Perkembangan itu terjadi karena terdorong adanya pembaharuan tersebut, sehingga di dalam pengajaranpun guru selalu ingin menemukan metode dan peralatan baru yang dapat memberikan semangat belajar bagi semua peserta didiknya. Bahkan secara keseluruhan dapat dikatakan bahwa pembaharuan dalam sistem pendidikan yang mencakup seluruh komponen yang ada. Guru sebagai salah satu komponen dalam proses belajar mengajar merupakan pemegang peran yang sangat penting. Guru bukan hanya sekedar penyampai materi saja, tetapi lebih dari itu guru dapat dikatakan sebagai sentral pembelajaran.

Guru selain sebagai pengatur sekaligus pelaku dalam proses belajar mengajar, gurulah yang mengarahkan bagaimana proses belajar mengajar itu dilaksanakan. Karena itu guru harus dapat membuat suatu pengajaran menjadi lebih aktif dan juga menarik sehingga bahan pelajaran yang disampaikan akan membuat peserta didik merasa senang dan merasa perlu untuk mempelajari bahan pelajaran tersebut. Pembelajaran di kelas harus disesuaikan untuk menekankan pada keaktifan siswa serta suasana pembelajaran yang meyenangkan sehingga hasil belajar siswa menjadi maksimal.

Berhasilnya suatu pembelajaran ditentukan oleh banyak faktor di antaranya adalah faktor guru dalam melaksanakan proses belajar mengajar, Karena guru secara langsung dapat mempengaruhi, membina dan meningkatkan kecerdasan serta keterampilan peserta didik. Untuk itu diperlukan suatu upaya dalam rangka meningkatkan mutu pendidikan dan pengajaran salah satunya adalah dengan memilih strategi atau cara dan motode dalam menyampaikan materi pelajaran agar diperoleh peningkatan hasil belajar peserta didik 
khususnya pelajaran IPA. Misalnya dengan mcmbimbing peserta didik untuk bersamasama terlibat aktif dalam proses pembelajaran dan mampu membantu peserta didik berkembang sesuai dengan taraf intelektualnya akan lebih menguatkan pemahaman peserta didik terhadap bahan yang diajarkan.

Dalam setiap pembelajaran, hasil belajar siswa merupakan suatu hal yang menjadi perhatian kerena dari hasil belajar itu akan diketahui bahwa pembelajaran tersebut telah berhasil atau belum. Setiap guru tentunya berusaha, supaya hasil belajar yang diperlukan lebih baik dari waktu ke waktu. Hal tersebut dilakukan untuk meningkatkan hasil belajar siswa, seorang guru dapat melakukan berbagai macam usaha, diantaranya dengan menggunakan, Metode, ataupun pendekatan yang bervariasi dalam mengajar. Seorang guru juga sebaiknya dalam proses belajar mengajar di dalam kelas menggunakan Metode pembelajaran yang sesuai dengan materi yang diberikan, agar siswa aktif dan belajar tersebut menyenangkan, bengitu juga halnya dalam pelajaran IPA yang diajarkan kepada siswa, sehingga dapat berubah sikap siswa yang sebelumnya menganggap IPA itu sulit dipelajari menjadi lebih mudah dipelajari dan menyenangkan. Keberhasilan siswa dalam belajar IPA juga sangat tergantung dari metode atau cara guru mengajar. Karena cara guru mengajar turut menentukan keberhasilan siswa dalam belajar.

IImu Pengetahuan Alam merupakan mata pelajaran yang wajib dipelajari siswa sekolah dasar. Pelajaran IPA berguna untuk memberikan pengetahuan kepada siswa mengenai fenomena-fenomena alam. Dengan, bengitu siswa bisa berfikir secara rasional berdasarkan pengetahuan mengenai fenomenan tersebut, menurut Widodo seperti yang dikutip Andi Maulana mengemukakan bahwa IPA atau Sains merupakan cabang IImu yang fokus pengkajiannya adalah alam dan proses-proses yang terjadi di dalamnya.

Oleh karena itu diharapkan guru selalu berupaya untuk meningkatkan mutu pembelajaran, khususnya pada pelajaran IPA, sehingga dapat meningkatkan hasil dan ketuntasan belajar siswa. Salah satu metode yang dapat di gunakan dalam melakukan proses bejalar mata pelajaran IPA adalah Metode pembelajaran discovery learning. Di mana metode pembelajaran discovery learning ini menjadikan peserta didik terlibat langsung dalam proses pembelajaran. Metode pembelajaran discovery learning adalah bantuan individual dalam kelompok dengan karakteristik pembelajaran bahwa tanggungjawab pelajar adalah pada siswa. Oleh karena itu, siswa harus membangun pengetahuan tidak menerima bentuk jadi dari guru.

Berdasarkan hasil observasi awal yang dilakukan di kelas IV SDN Tombo 02 terungkap bahwa pada saat pembelajaran IPA di kelas guru menggunakan metode ceramah dan metode percobaan pada pelajaran IPA. Metode tersebut masih kurang efektif dalam pelajaran IPA karena siswa tidak terlibat langsung dengan sumber pembelajaran secara maksimal. Aktivitas siswa cenderung pasif dan diam pada saat proses pembelajaran. Kemudian juga alat dan media pembelajaran yang digunakan guru masih kurang memadai dalam menunjang kegiatan pembelajaran. Hasil belajar siswa ratarata dari Evaluasi yang dilakukan oleh guru, nilai rata-ratanya adalah 65 . Nilai rata-rata tersebut belum memenuhi nilai KKM yang telah ditentukan adalah 74 .

Metode ceramah dan percobaan yang digunakan guru sudah baik dan sesuai dengan prosedur, siswa masih banyak yang tidak aktif, hal ini juga disebutkan oleh guru itu sendiri. Berdasarkan permasalahan di atas, penulis tertarik untuk melakukan penelitian lebih lanjut dengan judul "peningkatan kemampuan menganalisis hewan dan tumbuhan dilingkungan rumahku pada mata pelajaran ipa melalui metode discovery learning dengan pendekatan saintific siswa di Kelas IV SDN Tombo 02".

\section{METODE}

Penelitian Tindakan Kelas ini (Classroom Action Research) dengan menerapkan model discovery learning. Penelitian tindakan kelas ini terdiri dari empat tahapan dasar yaitu perencanaan (planning), pelaksanaan (acting), pengamatan(observing) dan refleksi (reflecting). Analisis penelitian ini adalah analisis deskriptif kuantitafif kualitatif dimana 
dalam penelitian ini selain penyajian hasil berupa data maupun angka peneliti juga menentukan bagaimana cara pengolahan hasil penelitian yakni dengan membuat analisisnya dengan menerapkan model discovery learning. Penelitian ini dilaksanakan pada peserta didik kelas IV SD Negeri 02 Tambo Tahun Pelajaran 2020/2021 selama dua siklus secara luring menggunakan penjelasan langsung dengan alat bantu LCD dan proyektor dengan satu pertemuan disetiap siklusnya. Siklus I dilaksanakan pada tanggal 10 November 2020. Siklus II dilaksanakan pada tanggal 17 November 2020. Teknik pengumpulan data yang dilakukan dengan observasi dan tes, baik pre test maupun post test. Observasi meliputi observasi keterlaksanaan dengan model discovery learning, sikap peserta didik dan keterampilan. Untuk hasil belajar menggunakan tes melalui LKPD dan evaluasi.

\section{HASIL DAN PEMBAHASAN}

Hasil belajar adalah suatu hasil atau kemampuan yang dicapai oleh siswa dalam memperoleh cara-cara bersikap dan betindak dalam proses belajar, model pembelajaran discovery learning dengan pendekatan santific, dapat diketahui bahwa hasil belajar adalah prestasi belajar yang dicapai siswa dalam proses kegiatan belajar mengajar dengan membawa suatu perubahan dan pembentukan tingkah laku seseorang. Tema Peduli Terhadap Makhluk Hidup Pembelajaran IPA dengan tema Peduli Dengan MakhlukHidup adalah berikut untuk kelas IV SDN Tombo 02 yaitu tentang hewan dan tumbuhan dilingkungan rumahku. Materi yang dipelajari disekolah dasar pada kelas IV. Materi hewan dan tumbuhan dilingkungan rumhaku yang diajarkan adalah yang terdiri dari makanan pokok Indinesia padi, jagung dan sagu. kompetensi dasarnya adalah: 3.1 Menganalisis hubungan antara bentuk dan fungsi bagian tubuh pada hewan dan tumbuhan dan 3.8 Menjelaskan pentingnya upaya keseimbangan dan pelestarian sumber daya alam dilingkungannya.

Seperti pada siklus pertama, siklus kedua ini terdiri dari perencanaan, pelaksanaan , observasi dan refleksi, untuk lebih jelasnya dapat diuraikan sebagai berikut :

1) Perencanaan

Perencanaan pada siklus kedua berdasarkan replaning siklus pertama yaitu :

a) Guru memberikan semangat dan otivasi kepada peserta didik dalam belajar

b) Guru memberikan waktu luang yang lebih untuk peserta didik yang masih mengalami kesulitan belajar menganalisis hewan dan tumbuhan

c) Memberikan dorongan dan pujian bagi anak yang telah mencapai ketuntasan dalam belajar menganalisis hewan dan tumbuhan

d) Membimbing dan memotivasi peserta didik yang nilainya masih dibawah KKM

e) Memberi penghargaan (reward)

f) Membuat perangkat metode discovery learning yang lebih baik lagi

2) Pelaksanaan

a) Suasana pembelajaran sudah lebih mengarah kepada metode discovery learning, peserta didik kelihatan lebih antusias mengikuti proses belajar mengajar yang disampaikan guru

b) Hampir semua peserta didik merasa termotivasi untuk menganalisis hewan dan tumbuhan bersama temannya

c) Sebagian besar peserta didik telah mengerti dan paham manfaat tumbuhan bagi manusia dengan benar

d) Suasana pembelajaran yang efektif dan menyenangkan sudah lebih tercipta, hal ini dapat dilihat dari partisipasi peserta didik dalam mengikuti proses pembelajaran melalui

Guru mengadakan tes pada peserta didik guna mengetahui sejauhmana cara berfikir kritis peserta didik dalam pembelajaran IPA

Observasi dan Evaluasi 
Hasil pemagatan keterlibatan belajar peserta didik siklus II dalam kegiatan pembelajaran IPA kelas IV SD Negeri Tombo 02 yaitu :

Pada siklus I pembelajaran dilaksanakan selama 2 pertemuan, setiap pertemuan diadakan pre test dan post tes. Untuk mengetahui peserta didik selama pembelajaran

Tabel 1 Hasil Belajar IPA kelas IV SD Negeri Tombo 02 pada siklus I

\begin{tabular}{ccccccccc}
\hline \multirow{2}{*}{ Siklus I } & \multicolumn{3}{c}{ Pre Test } & \multicolumn{3}{c}{ Post Tes } \\
\cline { 2 - 9 } & \multicolumn{2}{c}{ Pd. Tuntas } & \multicolumn{2}{c}{$\begin{array}{c}\text { Pd.Belum } \\
\text { Tuntas }\end{array}$} & Pd. Tuntas & \multicolumn{2}{c}{$\begin{array}{c}\text { Pd.Belum } \\
\text { Tuntas }\end{array}$} \\
\cline { 2 - 10 } & Jml & $\%$ & Jml & $\%$ & Jml & $\%$ & Jml & $\%$ \\
\hline Pertemuan 1 & 9 & 27 & 22 & 71 & 20 & 65 & 11 & 35 \\
\hline Pertemuan 2 & 11 & 35 & 20 & 65 & 23 & 74 & 8 & 26 \\
\hline
\end{tabular}

Berdasarkan tabel diatas maka terjadi peningkatan antara pre test dan post test. Setiap individu peserta didik sudah mengalami peningkatan belajarnya. Peningkatan klasikal juga mengalami peningkatan, pada pre test 9 anak yang sudah tuntas, pada post tes bertambah menjadi 20 anak yang sudah tuntas, dengan Kriteria Ketuntasan Minimal (KKM) sebesar 74. Demikian juga pada pertemuan 2 jumlah peserta didik yang sudah tuntas, sudah menjadi 23 peserta didik yang tuntas setelah melakukan post test.

Berdasarkan refleksi pada siklus i maka diputuskan untuk melanjutkan ke siklus II, dikarenakan belum mencapai ketuntasan klasikal yang diharapkan. Berikut ini adalah hasil belajar peserta didik pada siklus II yang bisa dilihat pada tabel berikut :

Tabel 2 Hasil Belajar IPA kelas IV SD Negeri Tombo 02 pada siklus II

\begin{tabular}{|c|c|c|c|c|c|c|c|}
\hline \multirow{3}{*}{ Siklus I } & \multirow{2}{*}{\multicolumn{2}{|c|}{$\begin{array}{l}\text { Pre Test } \\
\text { Pd. Tuntas }\end{array}$}} & \multicolumn{5}{|c|}{ Post Tes } \\
\hline & & & \multicolumn{2}{|c|}{ Pd.Belum Tuntas } & Pd. Tuntas & \multicolumn{2}{|c|}{ Pd.Belum Tuntas } \\
\hline & $\mathrm{Jml}$ & $\%$ & $\mathrm{Jml}$ & $\%$ & $\mathrm{Jml}$ & $\mathrm{Jml}$ & $\%$ \\
\hline Pertemuan 1 & 20 & 7 & 1 & 38 & 27 & 6 & 21 \\
\hline & & & 2 & & & & \\
\hline Pertemuan 2 & 27 & 8 & 7 & 18 & 28 & 3 & 14 \\
\hline
\end{tabular}

Berdasarkan tabel diatas maka terjadi peningkatan antara pre test dan post test. Setiap individu peserta didik sudah mengalami peningkatan belajarnya. Peningkatan klasikal juga mengalami peningkatan, pada pre test 20 anak yang sudah tuntas, pada post tes bertambah menjadi 27 anak yang sudah tuntas, dengan Kriteria Ketuntasan Minimal (KKM) sebesar 74. Demikian juga pada pertemuan 2 jumlah peserta didik yang sudah tuntas, sudah menjadi 23 peserta didik yang tuntas setelah melakukan post test. Perbandingan antara hasil post test pada pertemuan 1 dan pertemuan 2 juga terdapat perbedaan. Pada pertemuan 1 peserta didik yang sudah tuntas hanya ada 27 anak , sedangkan pada pertemuan 2 sudah meningkat menjadi 28 anak. Presentase ketuntasan kalsikalnya meningkat, jika pertemuan 1 hanya 83\% maka dipertemuan 2 menjadi $88 \%$

Setelah diterapkan metode discovery learning, maka kepala sekolah SD Negeri Tombo 02 bernama Bapak Budiman, S.Pd berpendapat bahwa motivasi peserta didik untuk belajar sudah mengalamai peningkatan dam metode discovery learning sudah dianggap tepat bagi peserta didik kelas IV. Begitu juga dengan teman sejawat, Bapak Trubus, S.Pd.SD juga menganggap hal yang sama dengan kepala sekolah.

Berdasarkan hasil siklus I dan II dapat disimpulkan bahwa dengan metode discovery learning dapat meningkatkan cara berfikir kritis peserta didik kelas IV SD Negeri Tombo 02 Kecamatan Bandar Kabupaten Batang 


\section{SIMPULAN}

Penerapan model Discovery Learning dapat meningkatkan hasil belajar peserta didik kelas IV SD Negeri Tombo 02 mata pelajaran IPA pada tema peduli terhadap makhluk hidup sub tema hewan dan tumbuhan di lingkunga rumahku. Peningkatan yang terdai karena adanya kesan pembelajaran yang mendalam dari peserta didik terhadap materi yang diajarkan melalui setiap proyek yang dibuat. Peserta didik akan selalu teringat akan materi yang diajarkan dikarenakan mereka menemukan dan membangun sendiri pengetahuan mereka pada saat membuat proyek yang sudah disepakati.

Aktivitas siswa dalam mengikuti pembelajaran pada tema peduli terhadap makhluk hidup dengan penerapan metode discovery learning sudah dikatakan berhasil, dikarenakan aktivitas siswa pada siklus I hanya $81,3 \%$ dengan kategori cukup dan pada siklus II menjadi 92,9\% dengan kategori sangat baik sekali. Hal ini dapat dilihat pada tabel hasil tes belajar siswa pada siklus kedua. Hasil tes belajar siswa secara klasikal pada tema peduli terhadap makhluk hidup dengan penerapan metode discovery learning sudah dikatakan berhasil. Hal ini dapat dilihat dari hasil post test pada siklus I belum mencapai ketuntasan secara klasikal, karena pada siklus ini rata-rata hasil tbelajarsiswa hanya $75,8 \%$ dan pada siklus II sudah mencapai ketuntasan secara klasikal dengan nilai ratarata $88,7 \%$

Berdasarkan penelitian yang telah dilaksanakan saah satu model pembelajaran yang harus dikuasai guru adalah Discovery Learning karena model ini sangat cocok digunakan dalam keadaan pandemi seperti saat ini. Apalagi dalam kondisi belajar dari rumah. Peserta didik akan membangun pengetahuannya sendiri dengan proyek yang sudah disepakati. Guru bisa memantau proses selama proyek dilaksanakan dengan bekerja sama dengan orang tua.

\section{DAFTAR PUSTAKA}

Arikunto, Arikunto. (2009). Penelitian Tindakan Kelas (PTK). Jakarta: Bumi Aksara.

Arikunto, Arikunto. (2009) Prosedur Penelitian atau Pendekatan Praktik. Jakarta: Bumi Aksara.

Dahar, Ratna Wilis. (2011). Teori-teori Belajar dan Pembelajaran. Jakarta: Raja Grafindo Persada.

Darminta, W.J.S.Poerwa . (1976). Kamus Umum Bahasa Indonesia, Cet. Ke- V. Jakarta: Pustaka Setia

Dimyati dan Mudjiono. (2006). Belajar dan Pembelajaran. Jakarta: Rineka Cipta

Dwi, Adi K. (2001). Kamus Praktik Bahasa Indonesi. Surabaya: Fajar Mulya

Ghony, Djunaidi. (2008). Penelitian Tindakan Kelas. Malang: UIN Malang Press

Hamalik. (2001). Teknik Pengukuran dan Evaluasi Pendidikan. Bandung: Pustaka Martian

Hosnan, M. ((2014). Pendekatan Saintifik dan Kontekstual dalam Pembelajar Abad 21. Bandung: Ghia Indonesia.

Ilahi, Mohammad Takdir. (2012). Pembelajaran Discovery Strategy dan Mental Vocantional Skill. Yogyakarta: Diva Press.

Istarani dan Muhammad Ridwan. (2014). 50 Tipe Pembelajaran Kooperatif. Medan: Media Pesada

Kunandar. (2008). Langkah Mudah Penelitian Tindakan Kelas. Jakarta: PT Raja Grafindo Persada.

Muslich, Mansur. (2010). Melaksanakan PTK :Penelitian Tindakan Kelas Itu Mudah (Classroom Action Research). Jakarta: Bumi Aksara. 
Nata, Abudin. (2011). Strategi Pembelajaran. Jakarta: Kencana

Poerwanto. (1994). Prinsip-prinsip dan Teknik Evaluasi Pengajaran. Bandung: Remaja Rosda Karya.

Rohani, Ahmad. (2004). Pengelola Pembelajaran. Jakarta: PT.Reneka Cipta Sadiman, Arif dkk. (2009). Media Pendidikan. Jakarta: Raja Grafindo Persada

Sudjana, Nana. (2005). Penilaian Hasil Proses Belajar Mengajar. Bandung: PT. Remaja Rosdikarya.

Suryabrata, Sumardi. (2008). Psikologi Pendidikan, Jakarta: Raja Grafindo Persada.

Syah, Muhibbin. (2006). Psikologi Pendidikan dengan Pendekatan Baru. Bandung: PT Remaja Rosda Karya. 